\title{
The effect of beaver facilitation on Common Teal : pairs and broods respond differently at the patch and landscape scales
}

\section{Nummi, Petri}

2019-04

Nummi , P , Suontakanen, E-M , Holopainen , S \& Väänänen, V-M 2019 , ' The effect of beaver facilitation on Common Teal : pairs and broods respond differently at the patch and landscape scales ', Ibis , vol. 161 , no. 2 , pp. 301-309 . https://doi.org/10.1111/ibi.12626

http://hdl.handle.net/10138/302629

https://doi.org/10.1111/ibi.12626

acceptedVersion

Downloaded from Helda, University of Helsinki institutional repository.

This is an electronic reprint of the original article.

This reprint may differ from the original in pagination and typographic detail.

Please cite the original version. 
2 The effect of beaver facilitation on Common Teal: pairs and broods

3 respond differently at the patch and landscape scales

4

5 PETRI NUMMI*, EEVA-MARIA SUONTAKANEN, SARI HOLOPAINEN \& VELI-MATTI

$6 \quad$ VÄÄNÄNEN

7

8 Department of Forest Sciences, University of Helsinki, P.O. Box 27, 00014 University

9 of Helsinki, Finland

10

$11 *$ Corresponding author.

12 Email: petri.nummi@helsinki.fi

$13+358054486160$

14

15 
Avian species respond to ecological variability at a range of spatial scales and according to life history stage. Beaver dams create wetland systems for waterbirds that are utilized throughout different stages of the breeding season. We studied how beaver-induced variability affected mobile pairs and more sedentary broods along with the production of Common Teal Anas crecca at the patch and landscape scale on their breeding grounds. Beavers Castor spp. are ecosystem engineers that enhance waterfowl habitats by impeding water flow and creating temporary flooding. Two landscapes in southern Finland with (Evo) and without (Nuuksio) American Beavers Castor canadensis were used in this study. To investigate the patch-scale effect, pair and brood densities along with brood production were first compared at beaver-occupied lakes and non-beaver lakes in the beaver landscape. Annual pair and brood densities/km shoreline and brood production were compared between beaver and non-beaver landscapes. Facilitative effects of beaver activity were manifest on brood density at both patch and landscape scales: these were over 90 and 60 percent higher in beaver patches and landscapes, respectively. An effect of beaver presence on pair density was only seen at the landscape level. Pair density did not strongly affect brood production, as shown earlier for relatively mildly density-dependent Teal populations. Because the extent of beaver flooding was a crucial factor affecting annual Teal production in the study area, we infer beaver activity has consequences for the local Teal population. Ecosystem engineering by the beaver could therefore be considered as a restoration tool in areas where waterfowl are in need of high-quality habitats.

Keywords: Anas crecca, brood production, Castor canadensis, ecosystem engineer, experienced scale, Teal density, wetland management 
Avian habitat selection, population stability and response to disturbance may differ according to the scale at which these are investigated (Wiens 1989a, Denny et al. 2004). Schneider (2001) identifies three scale-related problems which arise when ecological processes are studied. First, many ecological problems are often large in scale. Second, most variables can only be measured in small areas. Third, patterns or processes at small scales do not necessarily hold or prevail at larger scales (but see Denny et al. 2004). Sometimes the mechanisms underlying observed patterns operate at different scales than those at which the patterns are detected. Even investigators addressing the same questions, but at different scales, have been observed to reach differing conclusions (Wiens 1989b). Examples concerning birds include Least Flycatchers Empidonax minimus negatively influencing the distribution of American Redstart Setophaga ruticilla through interspecific aggression at the scale of four-hectare forest plots. At the regional level, however, the total abundances of the two species correlated positively (Sherry \& Holmes 1988). Similarly, variation in habitat use by sedentary Pied-billed Grebe Podilymbus podiceps was explained solely by within-patch variation whereas area requirements for vagile Black Tern Chlidonias niger, which forages up to four km away from the nest wetland, fluctuated in response to landscape structure (Naugle et al. 1999).

Beavers Castor spp. are ecosystem engineers of the boreal forest, creating disruption to riparian areas by their damming of creeks or ponds and forming of inundated areas (Naiman et al. 1988, Wright et al. 2003, Hyvönen \& Nummi 2008). Both American Castor canadensis and Eurasian Beaver C. fiber are assumed to have a similar effect on the riparian ecosystem (Danilov \& Fyodorov 2015) that would otherwise not exist in the landscape (Remillard et al. 1987, Johnston \& Naiman 1990, Nummi \& Kuuluvainen 2013). Beaver patches undergo succession from terrestrial to aquatic habitat and back, thereby increasing landscape heterogeneity (Remillard et al. 1987). Via ecosystem engineering, beavers may also act as facilitators for various species, such as plants (Wright et al. 2002), butterflies (Bartel et al. 2010), waterbirds (Nummi \& Holopainen 2014), and bats (Nummi et al. 2011). Therefore using beaver as a restoration tool for freshwater habitats has been suggested (Törnblom et al. 2011, Law et al. 2016).

Among boreal ducks, patch creation or modification by beavers has been found to especially benefit Common Teal Anas crecca, (hereafter Teal), as both Teal pairs and broods rapidly occupy newly formed beaver flowages (Nummi \& Pöysä 1997, Nummi \& Hahtola 2008). This has been attributed to both habitat modification and resource enhancement (sensu Bruno et al. 2003): beaver ponds provide more invertebrates that are potential food for Teal and have shallower depths - suitable 
for foraging - than non-disturbed boreal ponds (Longcore et al. 2006, Nummi \& Hahtola 2008). Compared to non-flooded lakes, Teal densities overall tend to be higher on beaver ponds due to greater numbers of pairs and broods, as well as elevated Teal duckling survival with ample foods there (Nummi \& Hahtola 2008).

As is the case for most organisms, ducks may experience their environment differently according to age, i.e. as a mobile flying adult compared to a more sedentary flightless duckling (Levin 1992). In our study we investigate how Teal pairs and unfledged broods (which clearly differ in their mobility) respond to environmental variation at patch $(0.1-50 \mathrm{ha})$ versus landscape scales $\left(40-50 \mathrm{~km}^{2}\right)$. The patches in our study are easily covered by both breeding pairs and broods within tens of minutes or 1-2 hours of swimming. In contrast, shifting between the most distant lakes within each landscape of our study would only take a few minutes for the flying pairs, but at least 15 hours (but most likely 1-3 days) for the non-flying broods (Martin \& Forsyth 1983, Duncan 1993). Duck pairs therefore typically have home ranges comprising many small wetlands and they travel a few kilometers between their foraging patches (Gilmer et al. 1975, Guillemain \& Elmberg 2014). We thus predict that the effect of spatial scale will differ between pairs and broods.

We hypothesize that Teal broods would be affected by beaver inundation already at the patch scale, whereas the beaver effect would be clearly seen in pairs at the landscape scale.

\section{METHODS}

\section{Study area}

Data were gathered in an oligotrophic watershed (area $\left.39 \mathrm{~km}^{2}\right)$ at Evo inhabited by American Beaver (hereafter Beaver) (61 $11^{\prime} \mathrm{N}, 2^{\circ} 07^{\prime} \mathrm{E}$; 51 lakes) and the Nuuksio lake area $\left(53 \mathrm{~km}^{2} ; 60^{\circ} 19^{\prime} \mathrm{N}, 24^{\circ} 28^{\prime} \mathrm{E} ; 54\right.$ lakes) in southern Finland not inhabited by Beavers (Arvola et al. 2010, Nyberg et al. 2010). The study lakes of both areas are oligotrophic, relatively small (Nuuksio $0.2-94.5$ ha, Evo 0.1-49.5 ha), have fish populations and are closed or headwater lakes (Väänänen et al. 2012). The predator communities of the two areas are similar with Pine Marten Martes martes and Red Fox Vulpes vulpes as main predators (Natural Resources Institute Finland 2017) 
along with two alien predators, the American Mink Neovison vison and Raccoon Dog Nyctereutes procyonoides. Ducks are additionally predated by several birds of prey and the Northern Pike Esox lucius.

Boreal forest covers most of the two areas, interspersed with lakes and mires. Agriculture and human settlement are very limited and local. Apart from Beavercreated variability in Evo, landscape-level habitat structure of the Evo and Nuuksio lakes has been fairly stable for the last 20 years (Suhonen et al. 2011, Thompson et al. 2016). In Evo, Beavers change their lake of occupancy on average every three years, thus new Beaver habitat patches are created continuously while old ones are abandoned (Hyvönen \& Nummi 2008). Lake shores in both study areas are generally steep, with little emergent vegetation (mainly sedges Carex spp. and Common Reed Phragmites australis), although some lakes have stands of Water Horsetail Equisetum fluviatile and cattail Typha spp. Emergent vegetation is usually lined with narrow belts of Yellow Water Lilies Nuphar lutea and Water Lilies Nymphaea candida; submerged vegetation is very sparse. Rocky shores are also typical in Nuuksio. In Beaver ponds the shores are significantly shallower than non-Beaver ponds and contain inundated herbaceous vegetation and bushes (Nummi \& Hahtola 2008). Located in a cool continental climate, all wetlands freeze over from November to April. Each spring, they are thus colonized anew by migrating ducks. Overall, the lakes of our two study areas were very similar and have been previously combined in waterbird studies (Nummi et al. 2012; Väänänen et al. 2012).

\section{Teal data}

In the Beaver landscape Evo duck data are from 1988-2014 and in non-Beaver landscape Nuuksio data are from 1994-2014. The number of pairs was estimated in both study landscapes once a year between the end of April and the beginning of May. The number of nesting pairs was interpreted using the survey guidelines of the Finnish Museum of Natural History (Koskimies \& Pöysä 1991). Brood data from the Beaver landscape were collected from 1988-2008 by conducting five annual brood surveys from June to August, and from 2009-2014 by conducting two annual surveys from June to July. In the non-Beaver landscape, the first brood survey was conducted in June and the second round in July. During each survey, a point count was first made from the shore, after which a round count was performed by circling the lakes by foot or boat (Nummi \& Pöysä, 1993); the method was chosen based on lake size and shoreline structure. In the most densely vegetated Beaver ponds all three methods (point count, circling by foot and circling by boat) were combined to attain coverage of the entire pond area. In Beaver ponds the ducks are most difficult 
to detect (see Holopainen et al. 2014), thus the number of birds found there are conservative. In both landscapes, all wetlands inside a certain area were surveyed.

Brood surveys included broods, ducklings without a female and also females emitting alarm signals. Duckling number was counted for every observed brood, after which the brood age was determined following the seven age classes of Pirkola and Högmander (1974). Age class was also estimated for ducklings seen without an adult female.

To eliminate the error caused by the irregularity in the number of annual brood counts, brood density was counted per survey in both study landscapes. In the comparison of Beaver and non-Beaver landscapes, we only took into account the two surveys (in June and July) in the Beaver landscape which corresponded to those of the non-Beaver landscape. Brood production was resolved by counting the number of broods per adult pair. The different age classes of the ducklings were not taken into account, but observations of juveniles were excluded. Thus, all sightings of the six age classes were taken into account, but they were not separated from one another.

Pairs and brood densities are given per km shoreline, thus information on shoreline length of the lakes and ponds in the study areas were required. Lake shore lengths in the Beaver study area were already measured by Nummi and Pöysä (1993). The shore lengths for the non-Beaver lakes and ponds, excluding a few small ponds, were obtained from the Finnish Environment Institute's open data service (syke.fi/avoindata). Shoreline length was measured for the remaining ponds using the same database's map service "Karpalo". Many lakes and ponds in the nonBeaver study area have a partly rocky shoreline, which is an unsuitable breeding environment for ducks. This amount of rocky shoreline was removed from the total shoreline length during analyses. Lengths of the rocky shorelines were measured using the map service of the Finnish Environment Institute (syke.fi/avoindata).

\section{Beaver data}

Both European and American Beavers were introduced to Evo during the 1930s and 1950s (Lahti \& Helminen 1974). Nowadays the Beaver population in Evo is comprised solely of American Beavers (Parker et al. 2012).

Since 1976, Beaver data have been collected from the lakes and ponds flooded by Beavers. The data indicate the years during which Beavers have flooded a lake or a pond. In Evo, Beaver ponds are most commonly formed by the damming of an 
existing pond (Nummi \& Hahtola 2008). Beavers occupy one site for an average of three years, and often return to the same areas they have flooded before (Hyvönen \& Nummi 2008).

\section{Patch-scale comparison of teal abundance before and during flooding}

On the patch scale we studied whether the Beaver increases pair and brood densities and brood production. The study was conducted in the Beaver area by comparing specific variables before and during a Beaver inundation in a patch. The goal of the comparison was to collect data two years before and two years during the flood. The density of only one year was used if Beaver-induced flooding had occurred for only one year in the patch.

Pair density was compared in 19 different lakes before and during Beaver inundation, and brood densities were similarly examined in 18 lakes. Brood production was also examined in 12 different lakes. These different figures result from the fact that in some cases the Beaver flood was only present in a certain lake during the pair time, and in some cases during the brood time, and in 12 cases both parameters were available. In each of these three cases, a control lake was included for each Beaver lake, representing the most similar lake along an environmental gradient of habitat luxuriance (Nummi \& Pöysä 1997). In control lakes especially the amount of broods remained extremely low which is the normal pattern in boreal lakes not affected by Beaver (Elmberg et al. 2005, Gunnarsson et al. 2004). The environmental gradient takes into account the shore's vegetation type, the amount of vegetation, water depth at the shore and lake size (Suhonen et al. 2011). The comparison was made using the Wilcoxon signed-rank test, which is a nonparametric version of the pairwise $t$-test (Ranta et al. 2012). The examination was made using the IBM SPSS Statistics 21 software (IBM Corp. 2012).

\section{Comparison of teal density in Beaver and non-Beaver lakes at Evo}

We also studied whether pair and brood densities and brood production differed in lakes with and without Beaver in the Beaver landscape. Lakes where data concerning Beaver floods were available during the study period were included in the data set. Altogether 24 Beaver-flooded lakes and 18 lakes with no Beaver activity during years 1988-2014 were included in the examination. We first tried to perform a glmm analysis using the individual lakes, and after data exploration ended up trying hurdle models (ZAP for broods an ZANB for pairs) with a random lake- 
effect. Unfortunately the lake level analysis could not be done with the glmm hurdle models, apparently because of so many zeros in both the Beaver occurrence column and teal column. Instead, the comparison was performed using the years when Beaver-induced floods occurred in the Beaver lakes, while all the years of the study period were used in the non-Beaver lakes. Annual average pair density was counted for each lake. Brood density was obtained using the years from 1988 to 2014. The same years were also used in examining pair density and brood production, excluding year 1988, from which no data on pair numbers were available. The comparison was made using the independent samples Mann-Whitney $U$-test by using the IBM SPSS Statistics 21 software (IBM Corp. 2012).

\section{Beaver and non-Beaver areas - comparing two landscapes}

We compared the annual brood and pair densities and brood production for 19942014 between the Beaver and non-Beaver landscapes. All pair and brood sightings of one year were added together, and brood density and broods per pair figures were transformed into figures per one survey. The comparison was made using the Mann-Whitney U-test, because the sightings were not normally distributed. Comparisons were performed using the IBM SPSS Statistics 21 software (IBM Corp. 2012). In addition to the difference between the study areas, we explored whether annual population variation differs within these two study areas. This annual variation was examined by testing the homogeneity of the variances with FlignerKilleen's test. Fligner-Killeen's test was chosen, because it also works well with samples that are not normally distributed (Ranta et al. 2012). Fligner-Killeen's test was conducted using the variation observed by Conover et al. (1981), in which the rank is counted using the median instead of plain values. The test was performed using R 2.3.2 software (R Core Team 2015).

\section{RESULTS}

\section{Patch scale}

Teal brood density in the ponds increased significantly with Beaver inundation ( $Z=-$ 2.24, $P=0.025, n=18$, Fig. 1 a), as did the median number of broods per pair ( $Z=-$ $2.02, P=0.043, n=12)$. Pair density, however, did not increase significantly $(Z=-1.6$, 
$P=0.110, n=19)$. In the non-flooded control lakes no significant change was found in either of the three cases ( $P>0.10$ in all cases, Fig. 1b).

\section{Within landscape}

Within the Beaver landscape, Teal brood density in Beaver ponds was again significantly higher than that of non-Beaver ponds, as was the number of broods produced per pair (Table 1). The pair density of Beaver and non-Beaver ponds did not differ significantly (Table 1).

\section{Between landscapes}

Teal pair density $(U=-5.18, P<0.001$, Fig. 2a), brood density $(U=-4.24, P=<0.001$, Fig. 2b), as well as the number of broods per pair $(U=-2.25, P=0.012$, Fig. $2 \mathrm{c})$ were significantly higher in the Beaver landscape (median: 0.34 pairs/ shoreline $\mathrm{km}, 0.03$ broods $/ \mathrm{km}, 0.11$ broods/pair) than in the non-Beaver landscape (0.15 pairs $/ \mathrm{km}, 0.01$ broods $/ \mathrm{km}, 0.08$ broods per pair). No significant differences were observed in the variability of pair or brood production per pair between the Beaver and non-Beaver landscapes (Fligner-Killeen test, $P>0.05$ in both cases). Brood density variability was higher in the Beaver landscape $\left(X^{2}=7.24, P=0.007\right)$.

\section{DISCUSSION}

We found scale-dependent patterns in the effects of Beaver on breeding Teal. Our study corroborated earlier observations that Beaver ponds increase the number of Teal broods at the patch scale (Nummi \& Hahtola 2008), the brood densities being over $90 \%$ higher during Beaver inundation. This finding was coupled with an increase in the number of broods produced per pair. The increase in Teal pairs upon Beaver flooding was not significant, contrasting the earlier study by Nummi \& Pöysä (1997). The results from these experimental-like situations of before and during inundation were supported when Beaver ponds and non-Beaver ponds within the Beaver landscape were compared: the densities of pairs and broods along with breeding success were eight to nine times higher in Beaver ponds. These observations fit the conceptual framework created by Levin (1992). He stated that 
localized disturbances play an important role in the maintenance of species such as the Teal which benefit from disrupted, high-quality habitats; in the case of Teal habitats with abundant invertebrates and shallow vegetated shores suitable for foraging (Nummi et al. 2013, Nummi \& Hahtola 2008).

When the Beaver and non-Beaver landscapes were compared, a similar picture emerged. Both the number of pairs and broods were significantly higher in the Beaver-influenced landscape than in the one which lacked Beavers. In the Beaver landscape the pair density was approximately $50 \%$ and brood density $60 \%$ higher than those found in the non-Beaver landscape. Similarly, the average number of broods per pair was higher in the Beaver landscape. We of course had only one landscape pair to compare, so possible other differences between the landscapes could not be effectively controlled. There appears to be no pronounced difference in general productivity between the two areas, since the densities of two other common ducks, Mallard Anas platyrhynchos and Common Goldeneye Bucephala clangula were similar in Evo (Nummi \& Pöysä 1995a) and Nuuksio (Taskinen 1997).

We found that the Beaver effect does not appear to emerge as clearly at the patch scale for pairs as it does for broods. However, pair density was also higher with Beaver influence at the landscape level. Once a pattern is detected, it is possible to concentrate on measuring its determinants and the mechanisms behind it (Levin 1992). In our case (at least) two mechanisms could bring about the pattern we observed. Firstly, although pairs might use Beaver ponds for foraging, they very likely encompass many small wetlands in their home range, and spend only part of their time in the Beaver flowages. This pattern has been shown for radio-tracked Mallards with home ranges of approximately 230 ha that include e.g. seasonal wetlands (Gilmer et al. 1975, see also Dwyer et al. 1979); individual breeding Teals have not been followed using radio telemetry but the home ranges of Teal pairs are approximately the same size as those of Mallard (Nudds \& Ankney 1982). Less mobile broods, again, may spend all of their time in the optimal Beaver ponds, once they have been discovered (Nummi \& Hahtola 2008; the home ranges of comparable Mallard broods were 10-15 ha; Talent et al. 1982, Chouinard et al. 2007). Secondly, and possibly more importantly, other flooded areas in riparian forests, namely seasonal wetlands created by melting snow, have been shown to be suitable for foraging during the pairing season (Paton 2005, see also Holopainen et al. 2014). This may dilute the Beaver flowage effect during springs when large amounts of flooded shores and vernal pools are available. 
At the landscape scale Teal broods were concentrated in the few Beaver patches of the Beaver landscape of Evo (Nummi \& Pöysä 1995b), while pairs were less so (Elmberg et al. 2005). The amount of Beaver flooding was also the most important factor affecting yearly Teal production in the area, among such environmental factors as food abundance (Holopainen et al. 2014). This could also be the reason why the brood density varied more in the Beaver landscape. Moreover, our finding that the average number of broods per pair was higher in the higher density Beaver landscape than in the lower density non-Beaver landscape corroborates our earlier study indicating that Teal populations may not show very strong spatial density dependence (Nummi et al. 2015). This supports the hypothesis that considering environmental variability, an association is often visible with a species' life history adaptation along a "slow-fast continuum" and temporary vs. permanent habitats (Fowler 1981, Sæther \& Engen 2002). "Fast" species typically live in habitats that are either unpredictable in time or short-lived, and those species themselves are often short-lived as well (Sæther \& Engen 2002).

Considering that $60-90 \%$ of European wetlands were lost during the last century and that similar figures apply to many areas of North America, there is great need for wetland restoration (Junk et al. 2013). From geomorphological, hydrological and ecological aspects introducing Beavers has the potential to be a mechanism for wetland restoration (Hey \& Philippi 1995, Burchsted 2010, Törnblom et al. 2011). Beavers are known to enhance biodiversity by beneficially affecting numerous groups of organisms (Stringer \& Gaywood 2016), sometimes facilitating whole species communities (Dalbeck et al. 2007, Nummi \& Holopainen 2014). Our data support earlier findings which consider Beavers as a feasible and economic way of restoring riparian landscapes (Brown \& Parsons 1979, Nummi 1989, Thompson et al. 2016).

We thank Tony Fox and two anonymous referees for valuable comments on the manuscript, and the numerous field workers for their help in the lakes. The grant from the Maj and Tor Nessling Foundation to S. H. and from the Foundation for Research of Natural Resources in Finland to P. N. are much appreciated.

\section{REFERENCES}


Arvola, L., Rask, M., Ruuhijärvi, J., Tulonen, T., Vuorenmaa, J., Ruoho-Airola, T. \& Tulonen, J. 2010. Long-term patterns in $\mathrm{pH}$ and colour in small acidic boreal lakes of varying hydrological and landscape settings. Biogeochem. 101: 269-279.

Bartel, R.A., Haddad, N.M. \& Wright, J.P. 2010. Ecosystem engineers maintain a rare species of butterfly and increase plant diversity. Oikos 119: 883-890.

Brown, M.K. \& Parsons, G.R. 1979. Waterfowl production on beaver flowages in a part of New York. New York Fish and Game Journal 26: 142-153.

Bruno, J.F., Stachovicz, J.J. \& Bertness M.D. 2003. Inclusion of facilitation into ecological theory. Trends Ecol. Evol. 18: 119-125.

Burchsted, D., Daniels, M., Thorson, R. \& Vokoun, J. 2010. The River Discontinuum: Applying Beaver Modifications to Baseline Conditions for Restoration of Forested Headwaters. BioScience 60: 908-922.

Chouinard Jr., M.P \& Arnold, T.W. 2007. Survival and habitat use of mallard (Anas platyrhynchos) broods in the San Joaquin Valley, California. The Auk 124: 13051316.

Conover, W.J., Johnson, M.E. \& Johnson, M.M. 1981. A Comparative Study of Tests for Homogeneity of Variances, with Applications to the Outer Continental Shelf Bidding Data. Technometrics 23: 351-361.

Dalbeck, L., Lüscher, B. \& Ohlhoff, D. 2007. Beaver ponds as habitat of amphibian communities in a central European highland. Amphibia-Reptilia 28: 493-501.

Danilov, P.I. \& Fyodorov, F.V. 2015. Comparative characterization of the building activity of Canadian and European beavers in northern European Russia. Russian J. Ecol. 46: 272-278.

Denny, M.W., Helmuth, B., Leonard, G.H., Harley, C.D.G., Hunt, L.J.H. \& Nelson, E.K. 2004. Quantifying scale in ecology: lessons from a wave-swept shore. Ecological Monographs 74: 513-532.

Duncan, D.C. 1983. Extensive overland movement of Pintail, Anas acuta, brood and attempted predation by hawks. Can. Field-Naturalist 97: 216-217.

Dwyer, T.J., Krapu, G.L. \& Janke, D.M. 1979. Use of prairie pothole habitat by breeding Mallards. J. Wildl. Manage. 43: 526-31. 
Elmberg, J., Nummi, P., Pöysä, H., Gunnarsson, G. \& Sjöberg, K. 2005. Early breeding Teal Anas crecca use the best lakes and have the highest reproductive success. Ann. Zool. Fennici 42: 37-43.

Fowler, C.W. 1981. Density dependence as related to life history strategy. Ecology 62: 602-610.

Gilmer, D.S., Ball, I.J., Cowardin, L.M., Riechmann, J.H. \& Tester, J.R. 1975. Habitat Use and Home Range of Mallards Breeding in Minnesota. J. Wildl. Manage. 39: 781789.

Guillemain, M. \& Elmberg, J. 2014. The Teal. T \& AD Poyser, London.

Gunnarsson, G., Elmberg, J., Sjöberg, K., Pöysä, H. \& Nummi, P. 2004. Why are there so many empty lakes? Food limits survival of mallard ducklings. Can. J. Zool. 82: 1698-1703.

Hey, D.L. \& Philippi, N.S., 1995. Flood reduction through wetland restoration: the upper Missisippi River Basin as a case history. Restor. Ecol. 3: 4-17.

Holopainen, S., Nummi, P. \& Pöysä, H. 2014. Breeding in the stable boreal landscape: Lake habitat variability drives brood production in the teal (Anas crecca). Freshwat. Biol. 59: 2621-2631.

Hyvönen, T. \& Nummi, P. 2008. Habitat dynamics of beaver Castor canadensis at two spatial scales. Wildl. Biol. 14: 302-308.

Johnston, C.A. \& Naiman, R.J. 1990. Aquatic patch creation in relation to beaver population trends. Ecology 71: 1617-1621.

Junk, W.J., An, S., Finlayson, C.M., Gopal, B., Květ, J., Mitchell, S.A., Mitsch, W.J. \& Robarts, R.D. 2013. Current state of knowledge regarding the world's wetlands and their future under global climate change: a synthesis. Aquatic Sci. 75: 151-167.

Koskimies, P. \& Pöysä, H. 1991. Waterfowl point count. In: Koskimies, P. \& Väisänen, R.A. (eds) Monitoring bird populations Zoological Museum, Finnish Museum of Natural History, Helsinki: 41-44.

Lahti, S. \& Helminen, M. 1974. The beaver Castor fiber (L.) and C. canadensis (Kuhl) in Finland. Acta Ther. 19: 177-189.

Law, A., Mclean, F. \& Willby, N. 2016. Habitat engineering by beaver benefits aquatic biodiversity and ecosystem processes in agricultural streams. Freshwat. Biol. 61: 486-499. 
421

422

423

424

425

Levin, S.A. 1992. The problem of pattern and scale in ecology. Ecology 73: 19431967.

Levin, S.A. \& Paine, R.T. 1974. Disturbance, patch formation, and community structure. Proc. Nat. Acad. Sci. 71: 2744-2747.

Longcore, J.R., McAuley, D.G., Pendelton, G.W., Bennatti, C.R., Mingo, T.M. \& Stromborg, K. L. 2006. Macroinvertebrate abundance, water chemistry, and wetland characteristics affect use of wetlands by avian species in Maine. Hydrobiologia 567: 143-167.

Martin, P.A. \& Forsyth, D.J. 1993. Survival and behaviour of captive Mallard broods exposed to carbofuran-sprayed vegetation: a field experiment. Ecotoxicology 2: 7992.

Naiman, R.J., Johnston, C.A. \& Kelley, J.C. 1988. Alteration of North American streams by beaver: the structure and dynamics of streams are changing as beaver recolonize their historic habitat. BioScience 38: 753-762.

Natural Resources Institute Finland 2017. https://www.riistakolmiot.fi/raportit (read 30th April, 2017).

Naugle, D.E., Higgins, K.F., Nusser, S.M. Johnson, W.C. 1999. Scale-dependent habitat use in three species of prairie wetland birds. Landscape Ecology 14: 267276.

Nudds, T.D. \& Ankney, C.D. 1982. Ecological correlates of territory and home range size in North American dabbling ducks. Wildfowl 33: 58-62.

Nummi P. 1989. Simulated effects of the beaver on vegetation, invertebrates and ducks Ann. Zool. Fennici 26: 43-52.

Nummi, P. \& Hahtola, A. 2008. The beaver as an ecosystem engineer facilitates teal breeding. Ecography 31: 519-524.

Nummi, P. \& Holopainen, S. 2014. Whole-community facilitation by beaver: ecosystem engineer increases waterbird diversity. Aquatic Conserv. 24: 623-633.

Nummi, P, Holopainen, S., Rintala, J. \& Pöysä, H. 2015. Mechanisms of density dependence in ducks: importance of space and per capita food. Oecologia 177: 679688.

Nummi P., Kattainen S., Ulander P. \& Hahtola A. 2011: Bats benefit from beavers: a facilitative link between aquatic and terrestrial food webs. Biod. Cons. 20: 851-859. 
453

454

455

456

457

458

459

460

461

462

463

464

465

466

467

468

469

470

471

472

473

474

475

476

477

478

479

480

481

482

483

484

Nummi P. \& Kuuluvainen, T. 2013. Forest disturbance by an ecosystem engineer: beaver in boreal landscapes. Boreal Environ. Res. 18: 13-24.

Nummi, P., Paasivaara, A., Suhonen, S. \& Pöysä, H. 2013. Wetland use by broodrearing female ducks in a boreal forest landscape: the importance of food and habitat. Ibis 155: 68-79.

Nummi, P. \& Pöysä, H. 1993. Habitat associations of ducks during different phases of the breeding season. Ecography 16: 319-328.

Nummi, P. \& Pöysä, H. 1995a. Breeding success of ducks in relation to different habitat factors. Ibis 137: 145-150.

Nummi, P. \& Pöysä, H. 1995b. Habitat use by different-aged duck broods and juvenile ducks. Wildl. Biol. 1: 181-187.

Nummi, P. \& Pöysä, H. 1997. Population and community level responses in Anasspecies to patch disturbance caused by an ecosystem engineer, the beaver.

Ecography 20: 580-584.

Nummi, P., Väänänen, V-M., Rask, M., Nyberg, K. \& Taskinen, K. 2012. Competitive effects of fish in structurally simple habitats: perch, invertebrates, and goldeneye in small boreal lakes. Aquatic Sci. 74: 343-350.

Nyberg, K., Vuorenmaa, J., Tammi, J., Nummi, P., Väänänen, V-M., Mannio, J. \& Rask, M. 2010. Re-establishment of perch in three lakes recovering from acidification: rapid growth associated with abundant food resources. Boreal Environ. Res 15: 480490.

Parker, H., Nummi, P., Hartman, G. \& Rosell, F. 2012. Invasive North American beaver Castor canadensis in Eurasia: a review of potential consequences and a strategy for eradication. Wild. Biol. 18: 354-365.

Paton, P.W.C. 2005. A review of vertebrate community composition in seasonal forest pools of the northeastern United States. Wetlands Ecol. Manage. 13: 235246.

Pirkola M.K. \& Högmander J. 1974. Sorsapoikueiden iänmääritys. (English summary: The age determination of duck broods in the field). Suomen Riista 25: 50-55.

Remillard, M.M., Gruendling, G.K. \& Bogucki, D.J. 1987. Disturbance by beaver (Castor canadensis Kuhl) and increased landscape heterogeneity. In: Turner, M. G. (ed.) Landscape Heterogeneity and Disturbance, Ecological Studies 64: 103-122. 
485

486

487

488

489

490

491

492

493

494

495

496

497

498

499

500

501

502

503

504

505

506

507

508

509

510

511

512

513

514

Sæther, B-E. \& Engen, S. 2002. Pattern of variation in avian population growth rates. Phil. Trans. Royal Soc. London B 357: 1185-1195.

Schneider, D.C. 2001. The rise of the concept of scale in ecology. BioScience 51: 545-553.

Sherry, T.W. \& Holmes, R.T. 1988. Habitat selection by breeding American Redstarts in response to a dominant competitor, the Least Flycatcher. The Auk 105: 350-364.

Stringer, A.P \& Gaywood, M.J. 2016. The impacts of beavers Castor spp. On biodiversity and the ecological basis for their reintroduction to Scotland, UK. Mammal Review 46: 270-283.

Suhonen, S., Nummi, P. \& Pöysä, H. 2011. Long term stability of habitats and use by ducks in boreal lakes. Boreal Environ. Res. 16 (suppl. B): 71-80.

Talent, L.G., Krapu, G.L. \& Jarvis, R.L. 1982. Habitat use by mallard broods in South Central North Dakota. J. Wildl. Manage. 46: 629-635.

Taskinen, K. 1997. Vesilintuyhteisöjen rakenne ja poikastuotto Nuuksion metsäjärvillä - pH:n, ravinnon ja ahventen määrän vaikutus sinisorsan ja telkän esiintymiseen alueella. MSc Thesis. University of Helsinki.

Thompson, S., Vehkaoja, M. \& Nummi, P. 2016. Beaver-created deadwood dynamics in the boreal forest. Forest Ecol. Manage. 360: 1-8.

Törnblom, J., Angelstam, P., Hartman, G., Henrikson, L. \& Sjöberg, G. 2011. Toward a research agenda for water policy implementation: Knowledge about beaver (Castor fiber) as a tool for water management with a catchment perspective. Baltic For. 17: 154-161.

Väänänen, V-M., Nummi, P., Pöysä, H., Rask, M. \& Nyberg, K. 2012. Fish-duck interactions in boreal lakes in Finland as reflected by abundance correlations. Hydrobiology 697: 85-93.

Wiens, J. A. 1989a. The Ecology of Bird Communities. Vol. 2. Processes and variations. Cambridge University Press, Cambridge.

Wiens, J. A. 1989b. Spatial scaling in ecology. Functional Ecol. 3: 385-397.

Wright, J.P., Jones, C.G. \& Flecker, A.S. 2002. An ecosystem engineer, the beaver, 
516 Fig. 1. Changes in Teal pair and brood densities as well as broods/pair per census in 517 Beaver flowages (black) and control ponds (grey). Shown are medians and 518 interquartile ranges. For pairs, $n=19$; for broods, $n=18$; for broods/pair, $n=12$.

519 Fig. 2. Teal pair (a) and brood densities (b) as well as broods/pair (c) at Beaver (Evo) 520 and non-Beaver (Nuuksio) landscapes during 1994-2014. 
523 Table 1. Teal pair density, brood density and broods produced per pair at the Beaver lakes and 524 control, non-Beaver lakes of Evo landscape. Test results indicate the independent Mann-Whitney 525 U-tests performed between the duck parameters of the Beaver lakes non-Beaver lakes. $\mathrm{SD}=$ 526 standard deviation; $Z=$ test value; significant results are bolded $(P<0.05)$. IQR $=$ interquartile 527 range.

\begin{tabular}{lccc}
\hline & $\begin{array}{c}\text { Beaver lakes } \\
(n=24)\end{array}$ & $\begin{array}{c}\text { Non-Beaver } \\
\text { lakes } \\
(n=18)\end{array}$ & Test results \\
\hline $\begin{array}{l}\text { Pair density } \\
\text { Median }\end{array}$ & 0.46 & 0.29 & $Z=-1.707 ; P=0.088$ \\
IQR & 1.31 & 0.33 & \\
Brood density & & & \\
$\quad$ Median & 0.06 & 0.00 & \\
IQR & 0.46 & 0.04 & \\
& & & \\
Broods/pair & & & \\
Median & & 0.01 & \\
IQR & 0.03 & 0.02 & \\
& 0.15 & & \\
\hline
\end{tabular}

